\title{
Spatial patterns of primate hunting in riverine communities in Central Amazonia
}

\author{
Priscila Maria Pereira, João Valsecchi and Helder Queiroz
}

\begin{abstract}
In many regions primates are an important dietary resource for isolated human populations, and they are among the most hunted species by traditional and indigenous communities in the Neotropics. Little is known about the characteristics or the spatial and temporal patterns of hunting, which limits a more detailed evaluation of its impact. We describe, quantify and analyse the spatial dynamics of primate hunting in the várzea (seasonally flooded forest) and paleovárzea (characterized by a series of low-lying ridges interspersed with flooded depressions, which result from cyclical depositional processes) environments of Central Amazonia, based on the monitoring of riverine communities at the Amanã and Mamirauá Sustainable Development Reserves over an 11-year period. During this time 402 primate hunting events were recorded, involving the harvesting of 541 individuals of nine species: Alouatta juara, Aotus cf. vociferans, Ateles chamek, Cacajao ouakary, Callicebus lucifer, Cebus albifrons, Saguinus inustus, Saimiri cassiquiarensis and Sapajus macrocephalus. Two hundred and forty of these hunts occurred in the paleovárzea and 162 in the várzea. The distances travelled by the hunters from their communities to the kill sites were significantly different between the environments, with longer distances being covered in the paleovárzea. Hunters in the paleovárzea also hunted across significantly larger areas than those in the várzea. The continuous monitoring of hunting areas and the gathering of data on the exploitation of species are necessary to understand the effects of hunting, as well as to support decision making in the management of the local fauna by traditional communities, and the development of effective conservation strategies for the local game species.
\end{abstract}

Keywords Amazonia, Brazil, geographical information system, GIS, hunting monitoring, paleovárzea, várzea

Supplementary material for this article can be found at https://doi.org/10.1017/So030605317000199

\footnotetext{
Priscila Maria Pereira (Corresponding author), João Valsecchi and Helder QueIroz Mamirauá Institute for Sustainable Development, Road Bexiga, 2584, District of Fonte Boa, Tefé City, Amazonas State 69553-225, Brazil

E-mail pris_map2@yahoo.com.br

Received 22 June 2016. Revision requested 28 September 2016.

Accepted 23 January 2017. First published online 1 June 2017.
}

\section{Introduction}

ubsistence hunting is a fundamental activity for many $\checkmark$ communities in tropical regions, especially as a source of dietary protein (Smith, 2008; Read et al., 2010; Linder \& Oates, 2011; Valsecchi et al., 2014; Constantino, 2015). In Brazil the use of wild animals for food is controlled by the Environmental Crimes Law (Law 9605, of 12 February 1998), which states that it is not a crime for a hunter, when in need, to hunt wildlife to feed himself or his family. However, there is some doubt about the interpretation of 'state of necessity' as mentioned in law, which precludes a clear understanding regarding the legality or otherwise of subsistence hunting. Furthermore, there is still a need for scientific studies to support the effective management and conservation of biological resources.

Primates are among the most preferred game species of the people who inhabit the tropical forests of South America, Asia and Africa (Levi et al., 2011; Fa et al., 2013; Quinten et al., 2014; Borgerson, 2015; Constantino, 2015). However, little is known about the spatial patterns of primate hunting. Most studies on hunting, and the models most frequently used to evaluate them, do not take spatial patterns into consideration, nor do they evaluate temporal distribution or the area affected (Bodmer, 1994; Robinson \& Bodmer, 1999; Sirén et al., 2004), which limits evaluation of the variation in the distribution of hunting grounds and hampers the identification of the factors that influence this variation. However, the spatial patterns of hunting activity are receiving increasing attention, providing new insights into the sustainability of this practice (Sirén et al., 2004; Smith, 2008; Levi et al., 2009; Read et al., 2010; Constantino, 2015).

Abiotic factors are among the main factors that influence the spatial distribution of game species, and hunting patterns. Soil type, hydrological conditions, anthropogenic impact, and habitat availability and use all contribute to the heterogeneity of the landscape (Eisenberg \& Thorington, 1973; Tilman \& Kareiva, 1997; Collinge, 2001; Valsecchi et al., 2014; Morcatty \& Valsecchi, 2015). This heterogeneity, in turn, influences the distribution and abundance of species (Peres, 1994) and affects hunting efforts and yields (Balée \& Gély, 1989; Bodmer, 1995, Morcatty \& Valsecchi, 2015). Hunting activity is also influenced by the accessibility of hunting grounds (Peres \& Lake, 2003; Sirén et al., 2004; Parry et al., 2009). For traditional communities in the Amazon, rivers are essential for movement and for access to many hunting areas (Smith, 2008; Constantino, 2015). 
New technologies have improved the efficiency of hunting practices, resulting in increased yields (El Bizri et al., 2015), and some of these technologies, in particular global positioning systems and geographical information systems, have become important tools for evaluating the spatial-temporal features of hunting activities (Brøseth \& Pedersen, 2000; Smith, 2008; Levi et al., 2011). A number of studies have shown that variation in hunting effort may affect the spatial-temporal impact of hunting on game species and their natural populations (McCullough, 1996; FitzGibbon, 1998).

A system for monitoring the use of local fauna was established in 2002 at the Mamirauá and Amanã Sustainable Development Reserves, in Central Amazonia in Brazil, to collect information on the use of local fauna by riverine communities, and evaluate the consumption of bushmeat and the stability of hunting in the two environments (Valsecchi et al., 2014). In both Reserves hunters move within the forest, walking on country roads and hunting trails, or travelling by canoe along rivers and other water bodies.

We monitored areas used for the hunting of primates over an 11-year period, and compared the spatial patterns of the harvesting of primates in the various environments used by local hunters. We tested the hypothesis that there was no increasing trend in the size of the areas used to hunt primates over time. We predicted that the hunting carried out in the study areas did not affect the populations of the targeted species, and therefore that the size of the hunting grounds had not increased (Valsecchi \& Amaral, 2009; Lopes et al., 2012). Primates are more abundant in the várzea forest (seasonally flooded forest, with nutrient-rich alluvial soils) than in the neighbouring forested environments, which are not subjected to periodic flooding (Peres, 1997). Thus, we also tested the hypothesis that the mean distance travelled by hunters in search of primates is shorter in the várzea forest compared to other environments, where primary productivity and primate abundance are lower, and that the hunting grounds are smaller in the várzea environment.

\section{Study area}

Mamirauá Sustainable Development Reserve (1,124,00o ha), officially protected since 1982 , is covered entirely by várzea forest (Ayres, 1995). It has a population of c. 11,532 inhabitants, in c. 200 small riverine communities (Moura et al., 2015b), whose principal subsistence activities are agriculture, fishing and hunting. The Solimões River floods every year, and the water level fluctuates by a mean of $10.6 \mathrm{~m}$ (Ramalho et al., 2009). This flooding pulse results in the deposition of sediments onto the soils of the Mamirauá várzea, which contributes to its high primary productivity (Junk et al., 2010). The Reserve is home to 11 primate taxa: Alouatta juara, Aotus cf. vociferans, Ateles chamek, Cacajao calvus calvus, Cacajao calvus rubicundus, Cebuella pygmaea, Pithecia cazuzai, Saimiri cassiquiarensis, Saimiri macrodon, Saimiri vanzolinii and Sapajus macrocephalus (Valsecchi, 2005; Paim et al., 2013; Cardoso et al., 2014; Marsh, 2014; Rabelo et al., 2014). We analysed data from the Fauna Use Monitoring System, a participatory monitoring initiative started in 2002 with the involvement of local inhabitants of riverine communities trained to record all hunting events, for five villages: Barroso, Boca do Mamirauá, São Francisco do Aiucá, São Raimundo do Jarauá and Sítio Fortaleza (Fig. 1; Table 1).

The c. 2,350,00o ha Amanã Sustainable Development Reserve was created in 1998. It has a population of c. 3,860 people, in 86 communities (Moura et al., 2015a), whose principal subsistence activities are agriculture, extraction of plant resources (e.g. Brazil nut and açaí, lumber), fishing and hunting. Amanã has a more diverse environment than Mamirauá, with flooded and non-flooded vegetation, including paleovárzea (characterized by a series of low-lying ridges interspersed with flooded depressions, which result from cyclical depositional processes; Irion, 1976), igapó (blackwater flood plains), várzea, terra firme (well-drained soils) and campinarana (a type of Amazonian high caatinga, savannah forests on white sandy soil) (Queiroz, 2005a; Irion et al., 2010; Assis et al., 2015). Areas of paleovárzea are used widely to hunt some game species, including primates (Valsecchi et al., 2014). Paleovárzea areas are adjacent to tracts of igapó that encompass Amanã Lake, which is $45 \mathrm{~km}$ long and $2-3 \mathrm{~km}$ wide, on average (Queiroz, 2005a). The paleovárzea is known by local residents as terra firme, a term normally applied in the Amazon Basin to higher grounds that are never flooded. In Amanã, however, the true terra firme habitats are far from the inhabited areas and are not exploited or used as hunting grounds by the communities monitored by the Fauna Use Monitoring System or in this study.

Eight primate species are present in Amanã: A. juara, A. cf. vociferans, Cacajao ouakary, Callicebus lucifer, Cebus albifrons, Saguinus inustus, S. cassiquiarensis and S. macrocephalus (Valsecchi, 2005; Valsecchi et al., 2010; Ferrari et al., 2014). We analysed data from Fauna Use Monitoring System records for three communities in Amanã: Boa Esperança, Bom Jesus do Baré and Nova Jerusalém (Fig. 1; Table 1).

From data and records from the monitoring system it was possible to identify distinct patterns of hunting, especially in the composition and frequency of the most hunted species in each area. Among the communities in the paleovárzea environments of Amanã, the preferred species are terrestrial mammals of medium and large size, such as white-lipped Tayassu pecari and collared peccaries Pecari tajacu, and pacas Cuniculus paca. In the várzea environments of Mamirauá the inhabitants make use of chelonians, 


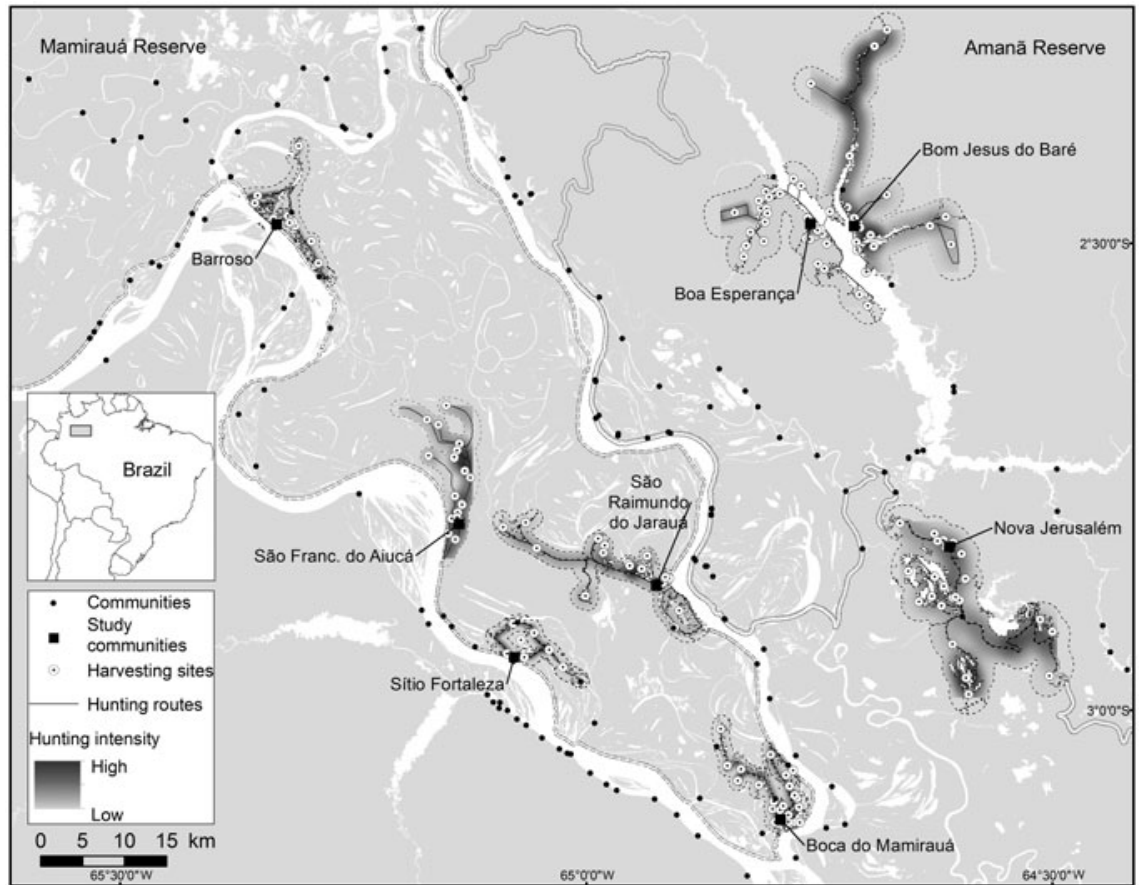

FIg. 1 The communities in Amanã and Mamirauá Sustainable Development Reserves in Central Amazonia, Brazil, monitored for primate hunting between 2003 and 2013, with the neighbouring communities, the hunting travel routes, the harvesting sites, and areas most intensively hunted by the study communities. medium and large birds, and howler monkeys Alouatta spp. (Valsecchi \& Amaral, 2009; Lopes et al., 2012). We believe the spatial-temporal patterns of hunting activity are also influenced by the environmental peculiarities that differentiate the two environments monitored.

In Amazonia white water rivers act as geographical barriers for some primate species (Wallace, 1852; Ayres \& Clutton-Brock, 1992; Ferrari, 2004). However, in the riverine communities studied, there are no barriers to hunters or primates in the areas used as hunting grounds. Local hydrography is therefore not a limiting factor for the composition of primate species hunted. However, some species of primates in the study areas have preferences for particular habitats in the landscape (Barnett \& Brandon-Jones, 1997; Barnett et al., 2013), and these preferences or habitat selection patterns can influence the composition of species hunted by the same communities.

\section{Methods}

\section{Data collection}

Data on the hunting of primates during January 2003December 2013 were derived from the Fauna Use Monitoring System (Valsecchi \& Amaral, 2009; Valsecchi et al., 2014). Usually, the hunters declared the information to trained members of each monitored community, who made notes and records. The main data recorded for each hunting event were the location of the harvesting, time invested in the hunt, number of hunters involved, hunting technique used, and details of the specimens harvested, such as their body length and weight, and reproductive condition, such as gestating or lactating (Valsecchi et al., 2014). The hunters provided this information voluntarily, and in some cases the body measurements of hunted animals were taken directly by the trained resident. Hunting events can involve one or more hunters, and one or more hunted animals, in a single location. Hunting can be intentional, when hunters leave home specifically for this purpose, or opportunistic, when the hunting event happens during unexpected encounters between hunters and wildlife. Usually the latter occurs when hunters are performing some other activity (e.g. agriculture or fishing).

The locations where primates were harvested were georeferenced using a global positioning system, with the assistance of local hunters. The travel routes used by the hunters within their hunting grounds were also georeferenced, which facilitated the determination of the area covered and the distance travelled.

\section{Mapping}

We produced maps of the hunting areas, and spatial metrics, in ArcGIS 10.2.2 (ESRI, Redlands, USA). To calculate the hunting areas, buffers were generated using the georeferenced hunting trails and locations of harvesting sites. These buffers varied in size between the two Reserves because of the difference in the mean distance travelled by the hunters from river banks (which are the main transport routes in the area) to the hunting grounds in the forest. The mean distance travelled was $1 \mathrm{~km}$ for hunters in the várzea forests and $2 \mathrm{~km}$ in the paleovárzea. Kernel density 
TABLE 1 Characteristics of the communities monitored between 2003 and 2013 in Mamirauá and Amanã Sustainable Development Reserves in Central Amazonia (Fig. 1), and spatial features of primate hunting by these communities (Supplementary Figs S1-S6).

\begin{tabular}{|c|c|c|c|c|c|c|c|}
\hline Community & Environment & Population & $\begin{array}{l}\text { No. of } \\
\text { years of } \\
\text { monitoring }\end{array}$ & $\begin{array}{l}\text { No. of } \\
\text { hunting } \\
\text { events } \\
\text { recorded }\end{array}$ & $\begin{array}{l}\text { Number of } \\
\text { harvesting } \\
\text { sites }\end{array}$ & $\begin{array}{l}\text { Total primate } \\
\text { hunting } \\
\text { area }\left(\mathrm{km}^{2}\right)\end{array}$ & $\begin{array}{l}\text { Mean distance travelled } \\
\text { to primate hunting areas } \\
\text { from home community, } \\
\mathrm{km} \text { (range) }\end{array}$ \\
\hline \multicolumn{8}{|c|}{ Amanã Sustainable Development Reserve } \\
\hline Boa Esperança & Paleovárzea & 252 & 11 & 147 & 31 & 136.799 & $8.65(0-25)$ \\
\hline Bom Jesus do Baré & Paleovárzea & 73 & 11 & 41 & 16 & 222.30 & $11.79(0.9-38.4)$ \\
\hline Nova Jerusalém & Paleovárzea & 231 & 9 & 53 & 24 & 263.10 & $15.03(0-40)$ \\
\hline \multicolumn{8}{|c|}{ Mamirauá Sustainable Development Reserve } \\
\hline Barroso & Várzea & 76 & 9 & 19 & 11 & 54.60 & $5.90(2-12.5)$ \\
\hline Boca do Mamirauá & Várzea & 66 & 9 & 61 & 24 & 66.58 & $6.20(0-17)$ \\
\hline São Francisco do Aiucá & Várzea & 66 & 7 & 27 & 19 & 82.76 & $6.47(0-20)$ \\
\hline São Raimundo do Jarauá & Várzea & 173 & 5 & 39 & 17 & 103.66 & $8.31(0.1-21.5)$ \\
\hline Sítio Fortaleza & Várzea & 111 & 4 & 15 & 6 & 41.17 & $5.70(0-17.8)$ \\
\hline
\end{tabular}

maps (heat maps) were created to identify the intensity of hunting within the study areas.

\section{Data analysis}

We used a $t$-test to compare the differences in the size of the hunting areas between the várzea and paleovárzea environments, as well as the distances travelled by the hunters, using each hunting event as a sample unit. Only intentional hunting events were considered in this analysis. This test was also used to determine whether the area used to hunt primates varied among years. This analysis was conducted separately for each of the communities monitored. The analyses were run in Excel 2007 (Microsoft Inc., Redmond, USA) and $R$ v. 3.1.1 (R Development Core Team, 2011), and results were considered to be significant at $\mathrm{P}<0.05$.

\section{Results}

During 2003-2013 the Fauna Use Monitoring System recorded 4,218 hunting events, with 10,992 animals harvested and consumed in the monitored communities. In 402 of these events the target species was a primate, of which 240 were recorded as harvested in the paleovárzea and 162 in the várzea. These hunting events resulted in the harvesting of 541 primate individuals of nine species. In the várzea, two species dominated, whereas three species dominated in the paleovárzea (Table 2).

In the paleovárzea, hunters used a mean hunting area of $105.18 \pm \mathrm{SD} 57.87 \mathrm{~km}^{2}$, whereas in the várzea the mean hunting area was significantly smaller, at $31.03 \pm \mathrm{SD}$ $19.07 \mathrm{~km}^{2} \quad(t=6.65508, \mathrm{df}=57, \mathrm{P}<0.001$; Table 1 ; Supplementary Figs S1-S6). No significant difference was detected in the sizes of the hunting areas used by the monitored communities over the study period. In six of the communities, the comparison of the size of the hunting grounds used during the first and last years of the study period indicated there was no significant change in the area exploited. Data from São Raimundo do Jarauá and Sítio Fortaleza spanned too short a timeframe to conduct this analysis ( 5 and 4 years, respectively).

The distances travelled by hunters differed significantly between the várzea and paleovárzea environments $(t=$ -2.451, $\mathrm{df}=41, \mathrm{P}<0.05$; Table 3 ). The mean distance travelled from the community to the harvesting site was $11.62 \mathrm{~km}$ in the paleovárzea environment, and $6.57 \mathrm{~km}$ in the várzea environment.

The frequency of the harvesting sites, distributed in distance classes from the home community, was unimodal in the várzea environment but bimodal in the paleovárzea environment. In the latter, harvesting sites $>20 \mathrm{~km}$ from the home community were used frequently for hunting primates (Fig. 2).

When the frequency distribution of distance to harvesting sites in the paleovárzea was analysed in terms of primate species it was observed that A. juara was hunted more severely in more distant places (in a monomodal distribution), whereas C. ouakary was hunted predominantly close to the home communities (also a monomodal distribution). Harvesting sites of $S$. macrocephalus were distributed along the hunting trails, with a bimodal distribution. Although in the paleovárzea harvesting sites located $>20 \mathrm{~km}$ from home communities were important for the hunting of $A$. juara and Sapajus macrocephalus (Fig. 3), in the várzea the harvesting of $A$. juara (the only species hunted heavily there) occurred mainly at short distances from the communities (monomodal distribution).

A majority of the harvesting sites in the paleovárzea (58) were located in areas of igapó or at the edges of water bodies, and only 13 sites are located further away, in the forests. The most intensely hunted areas were primarily in the vicinity of 
TABle 2 Primate species hunted in the várzea environment of Mamirauá Sustainable Development Reserve and the paleovárzea environment of Amanã Sustainable Development Reserve, in Central Amazonia (Fig. 1).

\begin{tabular}{lcc}
\hline & \multicolumn{2}{c}{$\begin{array}{c}\text { No. of individuals } \\
\text { harvested }\end{array}$} \\
\cline { 2 - 3 } Species & Várzea & Paleovárzea \\
\hline Howler monkey Alouatta juara & 204 & 101 \\
Night monkey Aotus cf. vociferans & 0 & 2 \\
Spider monkey Ateles chamek & 2 & $\star$ \\
Black uakari Cacajao ouakary & $*$ & 108 \\
Titi monkey Callicebus lucifer & $*$ & 12 \\
Capuchin monkey Cebus albifrons & $*$ & 4 \\
Mottle-faced tamarin Saguinus inustus & $*$ & 2 \\
Squirrel monkey Saimiri cassiquiarensis & 0 & 5 \\
Capuchin monkey Sapajus macrocephalus & 19 & 82 \\
Total & 225 & 316 \\
\hline
\end{tabular}

*The species does not occur in the environment.

the settlements and along the margins of the water bodies (Fig. 1). No systematic relationship was found between the number of harvesting sites used by a community and the size of its population ( $R s=0.25, \mathrm{P}>0.05)$ or the number of years of monitoring ( $\mathrm{Rs}=0.48, \mathrm{P}>0.05)$.

\section{Discussion}

The difference in the size of hunting areas between the two environments studied is probably attributable to the density of primates. Várzea environments, which are highly productive, usually support higher primate densities than paleovárzea environments (Peres, 1997; Queiroz, 2005b), and thus hunters can locate target species within a relatively small area. However, fishing was the main economic activity and source of animal protein for the várzea dwellers (Lopes et al., 2012; Valsecchi et al., 2014; Morcatty \& Valsecchi, 2015), which may explain the lower number of primates hunted in this environment, where the diet is based on aquatic animals such as fish, chelonians and alligators (Lopes et al., 2012; Morcatty \& Valsecchi, 2015).

The sizes of hunting grounds recorded were similar to those recorded in previous studies for all game species (Table 3). Most studies of hunting, including in the Amazon, have found that hunters rarely walk more than $10 \mathrm{~km}$ from their home community to their harvesting sites (de Thoisy et al., 2005; Smith, 2005, 2008; Peres \& Nascimento, 2006; Parry et al., 2009, Read et al., 2010; Constantino, 2015). However, few of these studies have discriminated between movements occurring within the forest, along country roads and hunting trails, and movement along rivers and other water bodies, in canoes. Franzen (2006), however, evaluated this aspect of hunting patterns among the Huaorani people in Ecuador, recording mean distances of $2.9,9.9$ and $14.5 \mathrm{~km}$ per hunt in three study communities, which were corrected to $2.8,4.2$ and $3.2 \mathrm{~km}$ per hunt, respectively, when only the forest environments were considered. In Central Amazonia most movements occur in canoes or small boats on rivers, channels or lakes (Fig. 1). When we analysed the hunting sites that were accessed by walking through the forest, the mean distance moved from the home community was $11.59 \mathrm{~km}$ in the paleovárzea and $3.24 \mathrm{~km}$ in the várzea. However, when the distance travelled by water was discounted, considering only the distance walked through the forest, the mean distances decreased to $2.06 \mathrm{~km}$ in the paleovarzea and $0.48 \mathrm{~km}$ in the várzea. The rivers of the Amazon, besides being important transit routes, are also used during subsistence activities, such as fishing and hunting, or for access to areas of family gardens (Fig. 1).

In Panama $100 \%$ of primate harvesting occurred within $7 \mathrm{~km}$ of the study communities, and $78 \%$ within $4 \mathrm{~km}$ (Smith, 2008). In Acre 95.9\% of all game hunting by the Kaxinawa people in terre firme forest occurred within 5 $\mathrm{km}$ of the village, and at least $65 \%$ was within $2.5 \mathrm{~km}$ (Constantino, 2015). In our study hunters travelled up to $40 \mathrm{~km}$ in the paleovárzea and $21 \mathrm{~km}$ in the várzea. During the 11 years of monitoring at least $30 \%$ of all captures of primates were recorded within $10 \mathrm{~km}$ of the hunter's home community. More distant harvesting sites were recorded for the communities that hunted in the paleovárzea, partly as a result of the specific history and cultural practices of the communities of Boa Esperança and Nova Jerusalém. Both settlements were previously located far from their present location. However, hunters still use those old sites (Alencar, 2007) and visit them for various activities, including hunting. We observed a relationship between spatial use for hunting activities and the distribution of water bodies, similar to that observed elsewhere (e.g. Panama, Smith, 2008; Peru, Ohl-Schacherer et al., 2007).

Harvesting of howler monkeys tended to occur in the vicinity of the communities in the várzea but at greater distances from the communities in the paleovárzea. This was expected, given the species' folivorous diet and relatively small home range size (Palacios \& Rodriguez, 2001; Jung et al., 2015), and its occurrence at high densities in the várzea environment of Mamirauá (Queiroz, 1995). In contrast, the frugivorous Cacajao ouakary occupies relatively large home ranges (Boubli, 1999), yet it was harvested in large numbers close to the communities in the paleovárzea. This may be because all of the communities monitored are surrounded by strips of igapó, which is the main habitat used by the C. ouakary during the dry season because of the abundance of unripe fruit (Barnett \& Brandon-Jones, 1997; Barnett et al., 2013).

Given the total population of the communities monitored (1,048 inhabitants), relatively few (148) sites were 
TABLE 3 Spatial features of hunting recorded in various studies in the Amazon biome, with locality, type of environment, number of communities monitored, population, mean hunting area, and data source.

\begin{tabular}{|c|c|c|c|c|c|}
\hline Locality & Type of environment & $\begin{array}{l}\text { No. of communities } \\
\text { monitored }\end{array}$ & Population & $\begin{array}{l}\text { Mean } \\
\text { hunting area }\end{array}$ & Source \\
\hline Central Amazonia & Várzea \& paleovárzea & 8 & 1,048 & $121.3 \mathrm{~km}^{2}$ & This study \\
\hline $\begin{array}{l}\text { Manu National Park, } \\
\text { Peru }\end{array}$ & Várzea \& terra firme & 5 & 1,988 & $151.5 \mathrm{~km}^{2}$ & $\begin{array}{l}\text { Ohl-Schacherer et al. } \\
\text { (2007) }\end{array}$ \\
\hline $\begin{array}{l}\text { Kayapó Indigenous } \\
\text { Territory, Pará, Brazil }\end{array}$ & $\begin{array}{l}\text { Cerrado-Amazon forest } \\
\text { transition zone }\end{array}$ & 1 & 1,946 & $117 \mathrm{~km}^{2}$ & $\begin{array}{l}\text { Peres \& Nascimento } \\
\text { (2006) }\end{array}$ \\
\hline Huaorani, Ecuador & Terra firme \& riparian forests & 3 & 220 & $239.7 \mathrm{~km}^{2}$ & Franzen (2006) \\
\hline Rio Jari, Amapá, Brazil & $\begin{array}{l}\text { Terra firme, Eucalyptus } \\
\text { plantation }\end{array}$ & 3 & $41^{1}$ & $77.6 \mathrm{~km}^{2}$ & Parry et al. (2009) \\
\hline $\begin{array}{l}\text { Kaxinawa Indigenous } \\
\text { Territory, Acre, Brazil }\end{array}$ & Terra firme & $\begin{array}{l}10 \text { Indigenous } \\
\text { Territories/33 } \\
\text { communities }\end{array}$ & 3,786 & $214 \mathrm{~km}^{2} 2$ & Constantino (2015) \\
\hline
\end{tabular}

${ }^{1}$ Number of families

${ }^{2}$ Mean area per Indigenous Territory

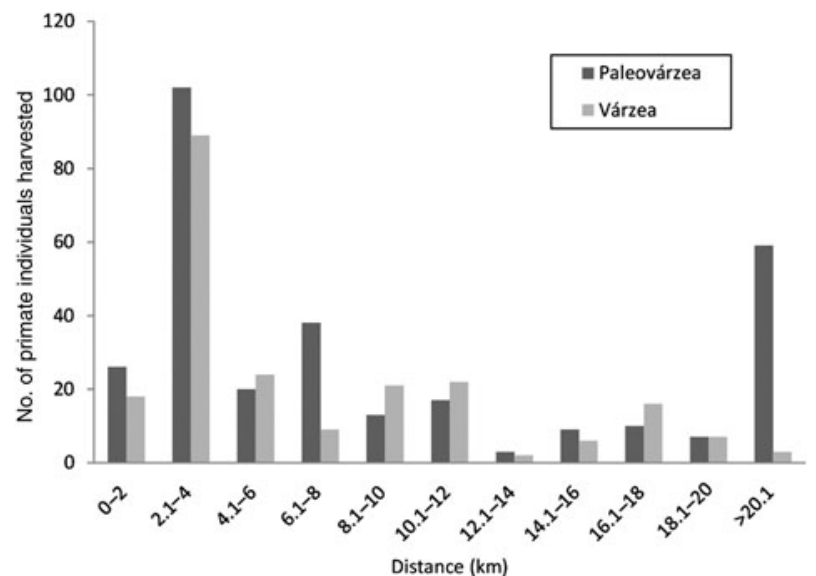

FIG. 2 Distribution of the total number of primates harvested during 2003-2013 in várzea and paleovárzea environments by communities in Amanã and Mamirauá Sustainable Development Reserves in Central Amazonia (Fig. 1), by distance of harvesting sites from the hunters' home communities.

used to harvest primates during the 11-year study period. Franzen (2006) recorded 101 harvesting sites (for all hunted species) during only 4 months of monitoring, in a study of 220 Huorani in Ecuador. In an 8-month study of the Buglé and Ngobe communities in Panama (725 residents), Smith (2008) recorded a total of 1,269 harvesting sites for all hunted species. It is possible hunting was the most important activity in these communities in terms of both subsistence and income generation, whereas in the communities of Mamirauá and Amanã hunting was of secondary importance and was a source of bushmeat but not of income.

Although many species of primates found in the study area are not among the preferred game species of the local communities (Valsecchi \& Amaral, 2009; Lopes et al., 2012), primates are a preferred dietary resource for some families

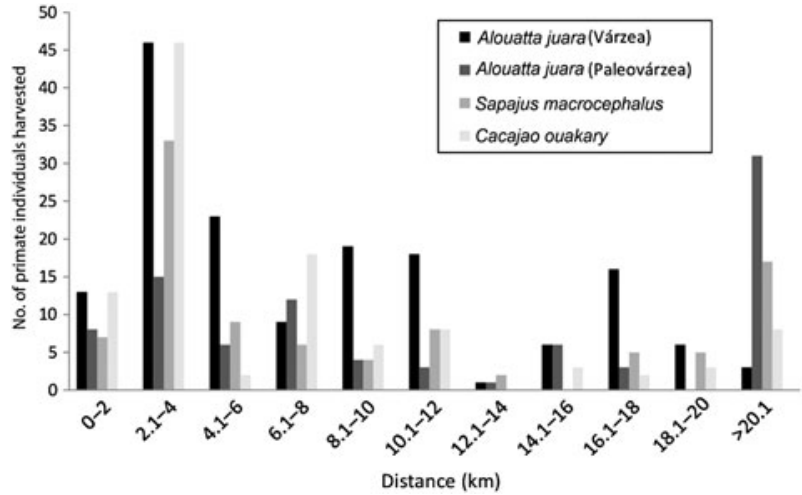

FIG. 3 Distribution of the three main primate species harvested during 2003-2013 by communities in Amanã and Mamirauá Sustainable Development Reserves in Central Amazonia (Fig. 1), by distance of harvesting sites from the hunters' home communities.

(authors, pers. obs.), and at least one primate species is among the most hunted game species in the region. Alouatta juara was the most hunted primate in the várzeas of Mamirauá and the second most hunted primate in the paleovárzea of Amanã. These findings reinforce the need for continuous monitoring of hunting areas, as well as analysis of their spatial variation over time, to understand the extent of the impacts of hunting pressure on local primate populations and to ensure the long-term food security of local communities.

The stability in the size of the areas used for hunting primates, the number of sites used and the distances travelled to hunting sites suggests that primate hunting in the region is not causing a significant reduction in natural capital, or else the removal of this biological resource is balanced by the replacement rate. The source-sink model described by Novaro et al. (2000) probably applies here, mainly in the 
paleovárzea areas, which are interconnected with continuous non-inhabited forests, serving as sources for the inhabited areas. The pattern in the spatial-temporal distribution of hunting during the 11-year study period corroborates models that point to possible sustainability of this activity. The model based on the differentiated productivity of the hunted species (Robinson \& Redford, 1991) would apply to the two environments under analysis, considering the spatial distribution of hunting (Figs $2 \& 3$ ) and the areas where there is a higher intensity of hunting (Fig. 1), showing that all monitored communities have in their proximity large areas where there is little or no primate hunting.

The spatial patterns of primate hunting in the study communities are probably similar to those found in other communities in the same or similar environments in Central Amazonia. Residents of communities in várzea areas are primarily fishers, for whom hunting is a secondary source of animal protein (Lima, 2005; Lopes et al., 2012). For communities in paleovárzea environments, prey populations are probably being supported by prey movements between source and sink areas (hunting areas).

We have shown that spatial analysis of hunting activities can provide important insights into hunting, as well as providing indicators of hunting sustainability in a given area. The spatial patterns of hunting may be used to inform the development of guidelines for the use of the fauna in a given area, with the participation of local inhabitants, as well as for the conservation of game species, especially those under the greatest pressure from hunting. The involvement of local communities in management decision making will ensure greater legitimacy and can broaden the recognition of regulations for the use of biological resources.

\section{Acknowledgements}

We thank the Fauna Use Monitoring System monitors and all the hunters who kindly helped in our research. We also thank the Mamirauá Sustainable Development Institute and the Ministry of Science and Technology for logistical and financial support for this research.

\section{References}

Alencar, E.F. (2007) Estudo da ocupação humana e mobilidade geográfica de comunidades rurais da Reserva de Desenvolvimento Sustentável Amanã - RDSA. Relatório Final, Santarém/Tefé, Brazil.

Assis, R.L., Haugaasen, T., Schöngart, J., Montero, J.C., Piedade, M.T.F. \& Wittmann, F. (2015) Patterns of tree diversity and composition in Amazonian floodplain paleo-várzea forest. Journal of Vegetation Science, 26, 312-322.

Ayres, J.M. (1995) As Matas de Várzea do Mamirauá: Médio Rio Solimões. Sociedade Civil Mamirauá, Tefé, Brazil.
Ayres, J.M. \& Clutton-Brock, T.H. (1992) River boundaries and species range size in Amazonian primates. The American Naturalist, 140, 531-537.

Balée, W. \& Gély, A. (1989) Managed forest succession in Amazonia: the Ka'apor case. In Resource Management in Amazonia: Indigenous Folk Strategies (eds D.A. Posey \& W. Balée), pp. 129-158. New York Botanical Garden, New York, USA.

Barnett, A.A. \& Brandon-Jones, D. (1997) The ecology, biogeography and conservation of the uakaris, Cacajao (Pitheciinae). Folia Primatologica, 68, 223-235.

Barnett, A.A., Defler, T.R., Oliveira, M., Queiroz, H.L. \& Bezerra, B. (2013) Cacajao ouakary in Brazil and Colombia: patterns, puzzles and predictions. In Evolutionary Biology and Conservation of Titis, Sakis and Uacaris (eds L.M. Veiga, A.

A. Barnett, S.F. Ferrari \& M.A. Norconk), pp. 359-367. Cambridge University Press, Cambridge, UK.

Bodmer, R.E. (1994) Managing wildlife with local communities in the Peruvian Amazon: the case of the Reserve Communal Tamshiyacu Tahuayo. In Natural Connections: Perspectives in Community-Based Conservation (eds D. Western \& R.M. Wright), pp. 113-134. Island Press, Washington, DC, USA.

Bodmer, R.E. (1995) Managing Amazonian wildlife: biological correlates of game choice by detribalized hunters. Ecological Applications, 5, 872-877.

Borgerson, C. (2015) The effects of illegal hunting and habitat on two sympatric endangered primates. International Journal of Primatology, 36, 74-93.

Boubli, J.P. (1999) Feeding ecology of black-headed uacaris (Cacajao melanocephalus melanocephalus) in Pico da Neblina National Park, Brazil. International Journal of Primatology, 20, 719-749.

Brøseth, H. \& Pedersen, H.C. (200o) Hunting effort and game vulnerability studies on a small scale: a new technique combining radio-telemetry, GPS and GIS. Journal of Applied Ecology, 37, 182-19o.

Cardoso, N.A., Valsecchi, J., Vieira, T. \& Queiroz, H.L. (2014) New records and range expansion of the white bald uakari (Cacajao calvus calvus, I. Geoffroy, 1847) in Central Brazilian Amazonia. Primates, 55, 199-206.

Collinge, S.K. (2001) Spatial ecology and biological conservation. Biological Conservation, 100, 1-2.

Constantino, P.A.L. (2015) Dynamics of hunting territories and prey distribution in Amazonian Indigenous Lands. Applied Geography, $56,222-231$.

De Thoisy, B., Renoux, F. \& Julliot, C. (2005) Hunting in northern French Guiana and its impact on primate communities. Oryx, 39, 149-157.

Eisenberg, J.F. \& Thorington, JR, R.W. (1973) A preliminary analysis of a neotropical mammal fauna. Biotropica, 5, 150-161.

El Bizri, H.R., Morcatty, T.Q., Lima, J.J.S. \& Valsecchi, J. (2015) The thrill of the chase: uncovering illegal sport hunting in Brazil through YouTube ${ }^{\mathrm{TM}}$ posts. Ecology and Society, 20, 30, http://dx.doi. org/10.5751/ES-07882-200330.

Fa, J.E., Farfán, M.A., Márquez, A.L., Duarte, J. \& Vargas, J.M. (2013) Reflexiones sobre el impacto y manejo de la caza de mamíferos silvestres en los bosques tropicales. Ecosistemas, 22, 76-83.

Ferrari, S.F. (2004) Biogeography of Amazonian primates. A primatologia no Brasil, 8, 101-122.

Ferrari, S.F., Guedes, P.G., Figueiredo-Ready, W.M. \& Barnett, A.A. (2014) Reconsidering the taxonomy of the black-faced uacaris, Cacajao melanocephalus group (Mammalia: Pitheciidae), from the northern Amazon Basin. Zootaxa, 3866, 353-370.

FitzGibion, C. (1998). The management of subsistence harvesting: behavioral ecology of hunters and their mammalian prey. 
In Behavioral Ecology and Conservation Biology (ed. T. Caro), pp. 449-473. Oxford University Press, New York, USA.

Franzen, M. (2006) Evaluating the sustainability of hunting: a comparison of harvest profiles across three Huaorani communities. Environmental Conservation, 33, 36-45.

IRION, G. (1976) Quaternary sediments of the upper Amazon lowlands of Brazil. Biogeographica, 7, 163-167.

Irion, G., de Mello, J.A., Morais, J., Piedade, M.T., Junk, W.J. \& Garming, L. (2010) Development of the Amazon valley during the Middle to Late Quaternary: sedimentological and climatological observations. In Amazonian Floodplain Forests: Ecophysiology, Biodiversity and Sustainable Management (eds W.J. Junk, M.T. E. Piedade, F. Wittmann, J. Schöngart \& P. Parolin), pp. 27-42. Springer, The Netherlands.

Junk, W.J., Piedade, M.T., Wittmann, F., Schöngart, J. \& Parolin, P. (eds) (2010) Amazonian Floodplain Forests: Ecophysiology, Biodiversity and Sustainable Management. Springer, The Netherlands.

Jung, L., Mourthe, I., Grelle, C.E.V., Strier, K.B. \& Boubli, J.P. (2015) Effects of local habitat variation on the behavioral ecology of two sympatric groups of brown howler monkey (Alouatta clamitans). PLoS ONE, 10(7), e0129789.

Levi, T., Shepard, G.H., Ohl-Schacherer, J., Peres, C.A. \& Yu, D.W. (2009) Modelling the long-term sustainability of indigenous hunting in Manu National Park, Peru: landscape-scale management implications for Amazonia. Journal of Applied Ecology, 46, 804-814.

Levi, T., Shepard, G.H., Ohl-Schacherer, J., Wilmers, C.C., Peres, C.A. \& Yu, D.W. (2011) Spatial tools for modeling the sustainability of subsistence hunting in tropical forests. Ecological Applications, 21, 1802-1818.

Lima, D. (2005) Diversidade Socioambiental nas Várzeas dos rio Amazonas e Solimões: perspectivas para o Desenvolvimento da Sustentabilidade. PróVárzea, Manaus, Brazil.

Linder, J.M. \& OAtes, J.F. (2011) Differential impact of bushmeat hunting on monkey species and implications for primate conservation in Korup National Park, Cameroon. Biological Conservation, 144, 738-745.

Lopes, G.P., Valsecchi, J., Vieira, T.M., Amaral, P.V. \& Costa, E. W.M. (2012) Hunting and hunters in lowland communities in the region of the middle Solimões, Amazonas, Brazil. Uakari, 8, 7-18.

MARSH, L.K. (2014) A taxonomic revision of the saki monkeys, Pithecia Desmarest 1804. Neotropical Primates, 21, 1-165.

McCullough, D.R. (1996) Spatially structured populations and harvest theory. The Journal of Wildlife Management, 60, 1-9.

Morcatty, T.Q. \& Valsecchi, J. (2015) Social, biological, and environmental drivers of the hunting and trade of the endangered yellow-footed tortoise in the Amazon. Ecology and Society, 20, 3, http://dx.doi.org/10.5751/ES-07701-200303.

Moura, E.A., Nascimento, A.C.S. \& CorrêA, D.S.S. (2015a) Censo Demográfico da Reserva de Desevolvimento Sustentável Amanã. Instituto de Desenvolvimento Sustentável Mamirauá, Tefé, Brazil.

Moura, E.A., Nascimento, A.C.S. \& Corrêa, D.S.S. (2015b) Sociodemografia da Reserva de Desenvolvimento Sustentável Mamirauá: 2001-2011. Instituto de Desenvolvimento Sustentável Mamirauá, Tefé, Brazil.

Novaro, A.J., Redford, K.H. \& Bodmer, R.E. (200o) Effect of hunting in source-sink systems in the Neotropics. Conservation Biology, 14, 713-721.

Ohl-Schacherer, J., Shepard, G.H., Kaplan, H., Peres, C.A., LEvi, T. \& YU, D.W. (2007) The sustainability of subsistence hunting by Matsigenka native communities in Manu National Park, Peru. Conservation Biology, 21, 1174-1185.

Palacios, E. \& Rodriguez, A. (2001) Ranging pattern and use of space in a group of red howler monkeys (Alouatta seniculus) in a southeastern Colombian rainforest. American Journal of Primatology, 55, 233-251.

Paim, F.P., de Silva Júnior, J.S., Valsecchi, J., Harada, M.L. \& Queiroz, H.L. (2013) Diversity, geographic distribution and conservation of squirrel monkeys, Saimiri (Primates, Cebidae), in the floodplain forests of Central Amazon. International Journal of Primatology, 34, 1055-1076.

Parry, L., Barlow, J. \& Peres, C.A. (2009) Allocation of hunting effort by Amazonian smallholders: implications for conserving wildlife in mixed-use landscapes. Biological Conservation, 142, 17771786.

Peres, C.A. (1994) Primate responses to phenological changes in an Amazonian terra firme forest. Biotropica, 26, 98-112.

Peres, C.A. (1997) Effects of habitat quality and hunting pressure on arboreal folivore densities in neotropical forests: a case study of howler monkeys (Alouatta spp.). Folia Primatologica, 68, 199-222.

Peres, C.A. \& LAKE, I.R. (2003) Extent of nontimber resource extraction in tropical forests: accessibility to game vertebrates by hunters in the Amazon Basin. Conservation Biology, 17, 521-535.

Peres, C.A. \& Nascimento, H.S. (2006) Impact of game hunting by the Kayapó of south-eastern Amazonia: implications for wildlife conservation in tropical forest indigenous reserves. Biodiversity and Conservation, 15, 2627-2653.

Queiroz, H.L. (1995) Preguiças e Guaribas - Os mamíferos folívoros arborícolas do Mamirauá. Estudos do Mamirauá. Volume II. Sociedade Civil Mamirauá, Tefé, Brazil.

Queiroz, H.L. (2005a) A Criação da Reserva Amanã e a Consolidação do Núcleo do Corredor Ecológico da Amazônia Central. In Os corredores Ecológicos das Florestas Tropicais do Brasil, 1st edition (eds J.M. Ayres, G. Fonseca, A. Rylands, H.L. Queiroz, L.P. Pinto, D. Masterson \& R. Cavalcante), 246-249. SCM, Belém, Brazil.

Queiroz, H.L. (2005b) A reserva de desenvolvimento sustentável Mamirauá. Estudos Avançados, 19, 183-203.

Quinten, M., Stirling, F., Schwarze, S., Dinata, Y. \& Hodges, K. (2014) Knowledge, attitudes and practices of local people on Siberut Island (West-Sumatra, Indonesia) towards primate hunting and conservation. Journal of Threatened Taxa, 6, 6389-6398.

R Development Core Team (2011) R: A Language and Environment for Statistical Computing. R Foundation for Statistical Computing, Vienna, Austria.

Rabelo, R.M., Silva, F.E., Vieira, T., Ferreira-Ferreira, J., Paim, F.P., Dutra, W. et al. (2014) Extension of the geographic range of Ateles chamek (Primates, Atelidae): evidence of river-barrier crossing by an Amazonian primate. Primates, 55, 167-171.

Ramalho, E.E., Macedo, J., Vieira, T.M., Valsecchi, J., Calvimontes, J., Marmontel, M. \& Queiroz, H.L. (2009) Ciclo Hidrológico nos Ambientes de Várzea da Reserva de Desenvolvimento Sustentável Mamirauá - Médio Solimões, período de 1990 a 2008. Uakari, 5, 61-87.

Read, J.M., Fragoso, J.M.V., Silvius, K.M. \& Luzar, J. (2010) Space, place and hunting patterns among Indigenous peoples of the Guyanese Rupununi region. Journal of Latin American Geography, 9, 213-243.

Robinson, J.G. \& Bodmer, R.E. (1999) Towards wildlife management in tropical forests. The Journal of Wildife Management, 63, 1-13.

Robinson, J.G. \& Redford, K.H. (1991) Neotropical Wildlife Use and Conservation. University of Chicago Press, Chicago, USA.

Sirén, A., НАмвӓCK, P. \& MACHOA, J. (2004) Including spatial heterogeneity and animal dispersal when evaluating hunting: a model analysis and an empirical assessment in an Amazonian community. Conservation Biology, 18, 1315-1329.

Smith, D.A. (2005) Garden game: shifting cultivation, indigenous hunting and wildlife ecology in western Panama. Human Ecology, $33,505-537$. 
Smith, D.A. (2008) The spatial patterns of indigenous wildlife use in western Panama: implications for conservation management. Biological Conservation, 141, 925-937.

Tilman, D. \& Kareiva, P. (1997) Spatial Ecology: The Role of Space in Population Dynamics and Interspecific Interactions. Princeton University Press, Princeton, USA.

Valsecchi, J. (2005) Diversidade de mamíferos e uso da fauna nas Reservas de desenvolvimento Sustentável Mamirauá e Amanã Amazonas - Brasil. MSc thesis. Museu Paraense Emílio Goeldi \& Universidade Federal do Pará, Belém, Brazil.

Valsecchi, J. \& Amaral, P.V. (2009) Perfil da caça e dos caçadores na Reserva de Desenvolvimento Sustentável Amanã, Amazonas Brasil. Uakari, 5, 33-48.

Valsecchi, J., El Bizri, H.R. \& Figueira, J.E.C. (2014) Subsistence hunting of Cuniculus paca in the middle of the Solimões River, Amazonas, Brazil. Brazilian Journal of Biology, 74, 560-568.
Valsecchi, J., Vieira, T.M., Silva Júnior, J.S., Muniz, I.C.M. \& Avelar, A.A. (2010) New data on the ecology and geographic distribution of Saguinus inustus Schwarz, 1951 (Primates, Callitrichidae). Brazilian Journal of Biology, 70, 229-233.

Wallace, A.R. (1852) On the monkeys of the Amazon. Proceedings of the Zoological Society of London, 20, 107-110.

\section{Biographical sketches}

Priscila Pereira works in the fields of scientific research and conservation, with a particular focus on hunting and the use of hunting grounds. JO ÃO VALSECCH I works mainly in the field of wildlife conservation, with a focus on wildlife hunting, ecology and conservation of mammals. HELDER QUEIROZ works on the ecology of flooded forests and the conservation of Amazon biodiversity, with particular emphasis on in-situ conservation in protected areas of the Amazon. 